\title{
SETO SINGING TRADITION IN SIBERIA: SONGS AND 'NON-SONGS'
}

\author{
Andreas Kalkun, Janika Oras ${ }^{1}$
}

\begin{abstract}
The article is based on fieldwork carried out in the 2000s among diasporic Setos living in Krasnoyarsk Krai, Russia, and discusses issues related to the singing tradition and identity of the Setos in this area. The article explores the ambivalent attitudes of the local singers towards their singing tradition and proposes a systematisation of the song tradition in the area into three groups Estonian songs, Russian songs, and Seto songs. The latter of the three represents the most archaic part of the Seto tradition, even though singers today no longer regard this part of the tradition as 'proper' songs, because of their improvisational and spontaneous nature. In addition to the ambivalence and confusion related to the identity and singing tradition, one can see conscious efforts in shaping identity politics and representing culture in Seto villages in Siberia. The best example of this is the Seto Museum and the choir active in Khaidak village. The generation of singers who are members of the choir today have discovered the old tradition in advanced age, but nevertheless find the singing of traditional songs highly significant. An important part of the contemporary identity politics of this tiny diasporic group is performing their exotic singing culture.
\end{abstract}

Keywords: diaspora, identity, Russian song, Seto song, Siberia, singing tradition, women's choirs

B: This is how we sing here; the tunes and all are the same. The same Seto people and the same Seto tunes. All these song tunes were brought back from Russia; our parents came here to sing and brought along their songs.

A: They came to live here.

B: Yes, came to live here and took the songs with them. [...]

A: They say that we are half-believers (polyvertsy). Our family comes from Audjasaare village [southeast Estonia]. ${ }^{2}$

My first field expedition to Seto villages in Siberia ${ }^{3}$ in July 2007 was replete with surprises. Although boasting considerable knowledge of the Seto culture in Estonia, I was astonished by this special amalgamation of the familiar and 
the unfamiliar. Although we seemingly spoke the same Seto language ${ }^{4}$, our occasional unconscious stumbling on some Russian or Estonian loan words gave away the differences in our linguistic and cultural background. While I had no problem joining the singing of some ancient ritual song or lyro-epic piece, I fell quiet, even though encouraged by the performers, when they picked up reportedly 'Estonian' folk songs to the tunes I had never heard before, or Russian folk songs that I was not familiar with either.

Some Estonian ethnologists who had carried out fieldwork in the area before had warned me that there was not much point in visiting the Setos in Siberia, because the old culture was on the verge of extinction. Indeed, the tangible and intangible culture of the Setos living in diaspora communities has transformed considerably over the past century, with much of the older tradition having disappeared or disappearing; however, we entertained no illusions of discovering anything congealed, musealised or untouched. It is inevitable, and not entirely tragic, that the tradition of the Setos in the diaspora has changed in time and is now different from what it was during their migration (see also Korb 2005). In Siberia we met communities who were aging, but some of them still spoke the Seto language and had a rich oral tradition. To our greatest surprise, we found a women's and children's choir active in Khaidak, the largest Seto village in Siberia. The choir fosters traditional choir singing and, like the Setos living in Estonia, the ones in Siberia greatly value the preservation of their song tradition. That being said, the attitudes of the Setos towards their song tradition were ambivalent: the spontaneous and improvisational Seto folk song, which is the most genuine part of the tradition, was not considered a 'proper' song, since it differed considerably from singing in Russian or Estonian style, in which the element of improvisation was not as central. The article attempts to delve further into the ambivalent attitudes of diaspora Setos towards their earlier song tradition. Since those knowledgeable about the tradition often emphasised in our conversations that the songs from the earlier layer of the tradition are not 'proper' songs, ${ }^{5}$ I have also used the local term 'non-songs' in this article. It should be noted, though, that I find this part of Seto song tradition by no means less important or non-existent.

The self-identity of the Setos in Siberia was equally fascinating. The informants had mostly heard from their parents and grandparents that they had migrated to Siberia from Rossiia ${ }^{6}$ (i.e., from the part of the Russian Empire to which the Seto region belonged at the time). At the same time, there was considerable confusion about the idea of motherland and the reasons why it was called Rossiia. Both the older and younger generations expressed similar confusion when referring to their ethnic identity. In the Soviet period, the Seto emigrants had 'Estonian' written as nationality in their passports, but many Setos perceived it as incorrect, since they did not speak Estonian and were 
aware of the clear difference between the Estonians and the Setos. Among the younger generation, the traditional identifying of oneself as Seto at home was equally confusing and brought no associations, because they had attended school in Siberia and had little knowledge of the Setos in Estonia. Many informants responded the researcher's question by saying, "You tell us who we are", and were pleased that ethnicity was not indicated in present-day passports of the Russian Federation. ${ }^{7}$

As pointed out in the article's motto, a conversation recorded in 1988, the self-identity of diaspora Setos is a fragile and contradictory mixture of internal and external representations. On the one hand, they are certain that they are 'the Seto people' and have 'Seto songs' and even remember the name of the village from which their (great-)grandparents once came. But, on the other hand, they say that they come from the ambiguous region of Rossiia, and call themselves disparagingly 'half-believers' by ethnicity. Curiously enough, the informants tended to associate their Seto identity with Seto songs, even to the degree that one informant, by a slip of the tongue, said that their parents came to sing there, instead of came to live there.

This ambivalence and confusion in the matters of identity persists even today, but there are also signs of emerging conscious efforts to construct one's identity politics and representation of culture, best demonstrated by the Seto Museum in the Khaidak village and the Seto choir active at the local community house. The choir makes appearances also elsewhere in the district and about once a year in the city of Krasnoyarsk, and is currently gaining popularity as a representative of exotic minority singing tradition.

In the following I will provide an overview of contemporary Seto song tradition in Siberia and explore issues of self-representation and -identity on the basis of observations and interviews made during the 2007, 2008 and 2012 field expeditions in the area. I have also made use of Igor Tõnurist's recordings from his 1987 and 1988 fieldwork expeditions in the same region. ${ }^{8}$

\section{WHO ARE WE? THE BACKGROUND OF THE IDENTITY PROBLEM}

In the late 19 th century and in the $1910 \mathrm{~s}$, many families ${ }^{9}$ emigrated from the overpopulated and poor Seto region at Lake Pskov to the then Yeniseiskii Gubernia, present-day Krasnoyarsk Krai. The Orthodox Christian Finno-Ugric Seto people were at the time designated in Estonian literature as Pskov or Pechersk Estonians (see Kreutzwald 1848; Hurt 1904a; Ustav 1908; Buck 1909). At the same time, ethnic Estonians did not see the Setos as their kinsfolk and thought 
of them as Russians, so that enlightened scholars of the humanities had to prove the kin ties to common Estonians even as late as at the turn of the century (Hurt 1989 [1904]: 145ff.). Russians, similarly, distanced themselves from the Setos and called them half-believers, alluding to the different interpretation of the Orthodox beliefs (see Kuutma 2006: 169ff.; Kalkun 2008; Honko et al. 2003). Since the Setos were illiterate at the time, there are no good sources to study the Seto self-identification of the period; however, there are some reports that in the 19th century they may have called themselves 'countryfolk'10, on the example of Estonians, or 'Russians', according to their religious affiliation (see Sarv 2000: 62), regardless of the fact that the Setos hardly spoke Russian at the time and mixed marriages of Estonians and Russians were extremely rare even as late as in the 1920s (Paas 1928).

The family names of the Setos who migrated to Siberia were derived from their patronymics, indicated in the documents, which means that upon settling in Siberia, the Setos with Orthodox names were given surnames like Matveev, Vasilev or Osipov. With the 1920 Tartu Peace Treaty, the Seto habitats at Lake Pskov became part of the Republic of Estonia and constituted Petseri (Pechory) County (see Raun 1991; also Raun 2007: 393). In 1921, the Setos were given Estonian surnames that Estonians would find pleasing to the ear (names in the Seto language were given less often, and Russian names were avoided altogether) and the integration of the Setos in the border areas and, according to the rhetoric of the time, the elimination of backwardness in the education and economic situation became the official policy of the Republic of Estonia. Alongside the changing of the language of education into Estonian, the administrative reform, the separation of mixed congregations and other reforms, the Setos of the region were rapidly modernised and Estonianised (Jääts 1998; Lõuna 2003).

As the emigration of the Setos fell into the period when they were illiterate, their contacts with relatives in the motherland remained problematic and soon disappeared entirely. Later, the correspondence was impeded by differences in education: since some were schooled in Russian and others in Estonian, they grew accustomed to writing the Seto language in either Cyrillic or Latin alphabet. By the 21st century, most Seto emigrants in Siberia had lost all contacts with their relatives in the motherland and only a few had memories of the last reciprocal visits that took place in the 1980s. Those who migrated to Siberia at the turn of the 20th century missed the changes that occurred in their country of birth, but the dramatic historical events began to change their lives as well. Men were mobilised to the First World War (1914-1918) and the Russian Civil War (1917-1922), the villages suffered from plundering, killings and wars. After the Bolsheviks' return to power, the entire religious 
life was banned and the new village churches in Khaidak, Perovo and Narva were closed down. All Estonian-language schools were also closed. While in the 1920s-1930s repressions it was the wealthier part of the population (e.g., the Setos who worked in gold mines) who suffered the most, the later repressions left almost no family untouched. The establishing of collective farms (kolkhozes) in the late 1930s disrupted the traditional way of life. Dispersed settlement and smaller Seto villages disappeared and gave way to new larger kolkhoz villages; part of the rural population urbanised, moving to larger cities and settlements. The Second World War emptied the villages from the remaining men and managing life in the villages became the responsibility of women and children. The villagers recall that life in the post-war period had been slightly better: collective farms flourished, people were paid in cash, but the younger generation continued to leave the countryside in search for better living and working conditions. The Seto villages of the present-day Krasnoyarsk Krai were gradually turned into Russian-speaking multi-ethnic villages with an aging and diminishing population due to the disappearance of collective farms and local employment and the 'youth drain'. Older women, living on state pension, now dominate in the villages.

\section{TWO GENERATIONS OF SINGERS}

Incidentally, in Seto villages both in Siberia and in the motherland, it is the women who uphold the singing tradition. Already at the end of the 19th century, collectors of folklore who visited the Seto region, wishing to record the singing of male bards, complained that they "had to be satisfied" with women's songs, which were still widely available at the time. ${ }^{11}$ In a patriarchal Seto village, traditionally homebound women remained less affected by modernisation and globalisation than their husbands. Therefore women held on to old traditional clothing, religious practices and lifestyle more conservatively, and also remained the main transmitters of the community's oral tradition. Also, the village choirs of the Soviet period were largely a female phenomenon. ${ }^{12}$ While the generation gap in the singing tradition of men occurred already before the wars and repressions, which further destroyed the traditional men's culture, the disruption in women's culture took place much later. The Seto women in Estonia, who sang in official village choirs in the Soviet period, usually wore traditional garments made by their grandmothers and remembered their songs. Seto women in Siberia abandoned traditional garments much earlier (see Piho 1994), but the women who sang in community house choirs claimed that they envisioned their grandmothers' performance style and thus even this official form of singing entailed a personally intimate and nostalgic aspect. 


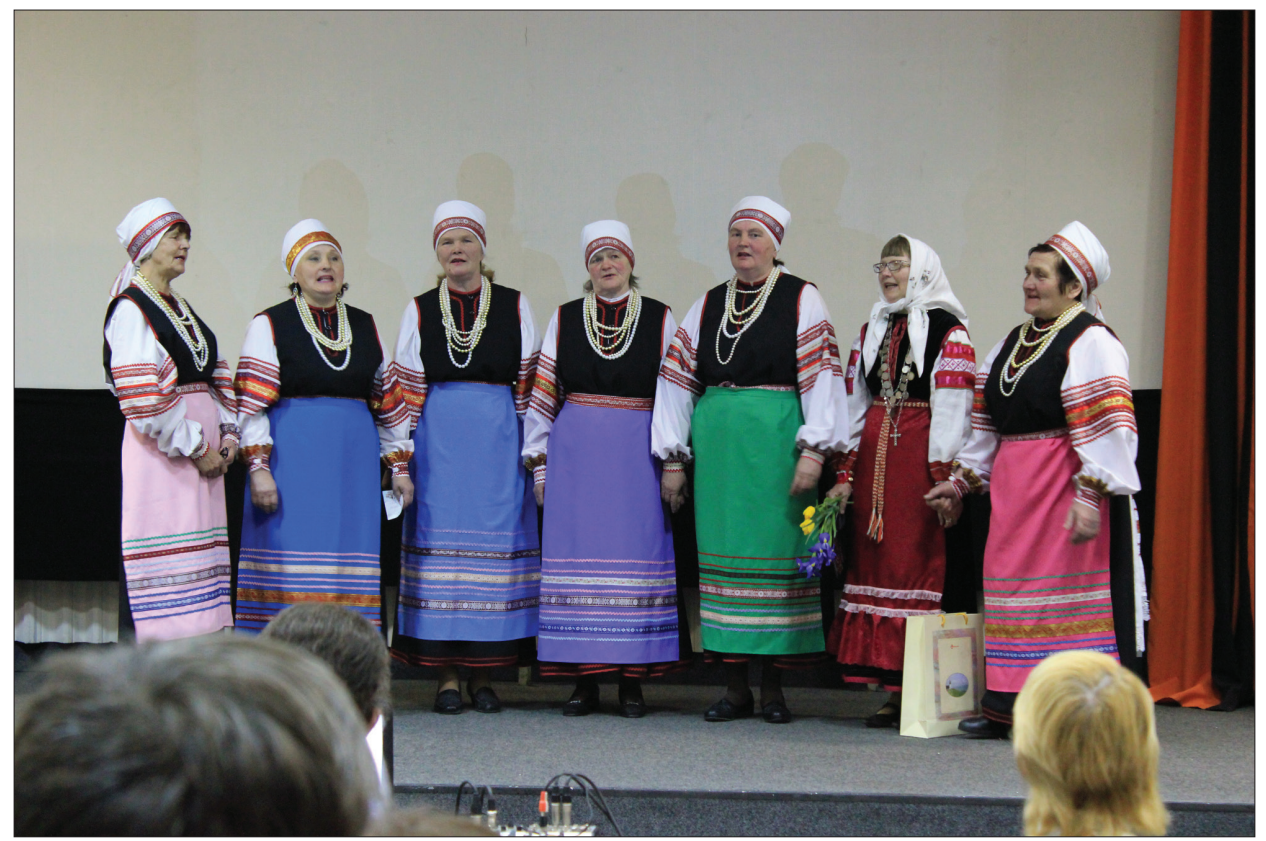

Figure 1. The Khaidak village choir Lill at the anniversary of the Krasnoyarsk Estonian Society. Lidia Ponomarchuk, Tanja Medetskaia, Olga Ivanova, Alidia Stepanova, Anna Kucherenko, Galina Evseeva and Maria Ossipova. Photograph by Andreas Kalkun 2012.

For Seto women in Siberia, singing in a group ${ }^{13}$ is a way to construct their identity both in the public and private spheres (cf. Olson \& Adonyeva 2012). On the one hand, singing is a public activity, which has been partly supported by the state through the local community house during and after the Soviet period. This official form of singing in a community house has been a source of emancipation for the women and has given them a chance to temporarily leave the domestic sphere or work on the collective farm, and participate in organised cultural life and travel. On the other hand, for the village women's community singing in a group represents an internal intimate form of communication, which has united different generations and has helped to preserve the tradition of the ethnic group and family with varying degrees of success at different times. Singing at home and among friends at feasts on calendar or other holidays has strengthened the sense of 'us' and associated a part of the repertoire with specific persons.

The singing of the Setos in Siberia is definitely not limited to the women in the community house choir and formal performances. During fieldwork I had a 
chance to take part in St. John's Day celebrations and some birthday celebrations in the village, at which singing in different languages and styles played a prominent role. There are a remarkable number of women in the Khaidak village who know Seto and Estonian songs and break out singing at the spur of the moment and at formal events. ${ }^{14}$ The most prominent representative of the lively singing tradition, however, is certainly the women's choir Lill (Flower), which comes together in Khaidak community house. The choir has been active for nearly twenty years, with varying degrees of intensity and a changing membership. Many local women have sung in the choir during its existence. Some have participated until their deaths, others have left the choir due to advanced age, some have sung in the choir for a long time, others for shorter periods. Over the period of our fieldwork, the choir had a relatively stable membership, with a leading group of three women, ${ }^{15}$ who used to work together as milkmaids before retirement. Other choir members were community house employees, who were younger than the leading trio, as well as some even younger women who participated less regularly. ${ }^{16}$

The three women who formed the choir's core belong to a generation who sang only Russian songs in their youth. Theirs was the first generation who was not educated in the Estonian language and had to adopt Russian, to the best of their abilities. This generation was also the first in which mixed marriages with Russians and moving away from the village became more common. ${ }^{17}$ As the women had heard Seto songs in their youth, sung by elderly villagers at home and public village events, they all had at least passive knowledge of the Seto singing style since the early age.

Maria P: Older women used to sing Seto songs when they got together at feasts.

Lidia K: When our mothers were young, nobody sung Russian songs. These became popular only when we went to school. We never sang Seto songs back then, when we were attending school. We didn't even know any. The older women sang these, but we hardly paid any attention.

Maria P: We are the post-war children, our teachers were Russians; the Seto / Estonian language was no longer taught at school.

Maria O: But our parents went to an Estonian-language school.

Lidia K: Well, some did, some didn't. My mother couldn't even write her own signature. ${ }^{18}$ (Khaidak village, July 2007)

The repertoire of this generation of women contained fewer songs related to family and calendar rituals, and more Soviet romances and popular songs learned from public media channels. When talking about their youth, the women agree that they used to sing Seto songs only "in jest". The women recalled that in 
these days Seto songs were sung while drinking, at small private parties and gatherings of women who worked together on the collective farm. At such events, singing was led by women who had learned Seto songs from their parents or who knew how to improvise on current day-to-day topics. The women did sing ancient songs in Seto style, but their generation had replaced the traditional ritual functions with entertainment purposes.

Lidia K: Maria P., Maria O. and I, we started to sing together. When we were invited to give concerts, we started to rehearse those Estonian and Seto songs as well. We never used to rehearse before; sometimes when drinking on the farm, my cousin, Timmo's Vera, was the lead singer. We usually sang when we were drinking. When we worked together with Anastasia, we sometimes sang these songs in jest, she knew them, we said davai, let's sing some Seto or Estonian song too. (Khaidak village, July 2008)

At the same time, for the women singing in the community house choir, the old ritual songs brought back memories of some former performances or the village women who used the same melodies. For example, a Shrovetide song, an Easter swinging song or a St. Catherine's Day song, but also songs sung at a Seto women's feast reminded them of earlier performance situations, so that singing these songs was also related to remembering the nostalgic lost times or past youth. The younger generation of singers admired the ability of older singers to improvise new lyrics on the go and found it particularly amusing that their mothers broke into singing at public village events even at an old age. ${ }^{19}$

The generation older than the choir leaders did not sing in the community house choir and thus their recollections about singing and performance situations were far more versatile and clearly different. ${ }^{20}$ They recalled songs sung when doing the household chores, laments at weddings and funerals, and mentioned song fragments that for some reason were significant enough to be remembered over dozens of years. Already in the material recorded in 1987 and 1988 in Khaidak village, people spoke about someone called Semmeni Olli ${ }^{21}$, who could sing so that "the village echoed back" when herding cattle. The younger generation of female singers spoke of the same thing in the late $2000 \mathrm{~s}$ and the woman herself agreed. Olga M. was one of the remarkable singers of the older generation, who had a vast repertoire, had never sung in an official choir, but readily sang alone or joined in spontaneously formed groups. In an interview, Olga M. regretted that she had not gone herding for a while and was starting to forget the song lyrics. Being a village herder at a rather old age, Olga M. used to sing traditional herding songs and other Seto songs, but by 2000 spontaneous singing during work in the open air had become a thing of the past in the village, and it happened, on rare occasions, only when drunk or old people were involved. 


\section{THREE SINGING STYLES}

The Setos in Siberia have incorporated songs and music of different origin into their repertoire. They have learned sentimental end-rhymed ballads in both southern and northern Estonian language from their south-Estonian neighbours, and adopted popular Russian songs from their Russian neighbours. ${ }^{22}$ As far as music, texts, language and particularly the level of stability are concerned, the end-rhymed and stanzaic 'Estonian' and Russian songs differ considerably from the 'Seto songs' - the songs in the special runo song style, which is characterised by a specific meter, figurative language, alliteration and variability of texts.

The Seto songs recorded in Siberia in 1987 and $1988^{23}$ suggest that the most predominant style at the time was the Seto song, seeing that the newer rhymed 'Estonian' song constitutes about one-tenth of the entire recorded song material. The complete absence of Russian-language songs in these recordings points to the selective criteria of the recording event: valuable tape capacity was, possibly deliberately, saved for what was considered the oldest and allegedly "more valuable" part of the singing tradition..$^{24}$ In the course of our fieldwork, we noticed that the representatives of the older generation, who did not sing in choirs, were less familiar with Russian songs and did not join in singing these in social situations. In the repertoire of women in the choir, however, Russian songs constituted almost a half, with the remaining half left to Estonian and Seto songs.

The different singing styles have certainly affected each other, but the singers whom we met during our 2007 and 2008 fieldwork trips perceived the difference between the singing styles very acutely. The Setos in Siberia, for example, believe that the fact that the singing style known as the Seto song allows a good singer to improvise new lyrics for each occasion and combine known 'words' 25 with new ones, while remaining true to traditional formulas and metrics, makes the Seto song completely different from Estonian and Russian songs.

The Seto song is based on the 8-syllable metre widely spread in the Baltic Finnish region (generally called regilaul, runo song or Kalevala-metric song) and follows a specific poetic model (see Example 1). The melodies of earlier Seto song types are based on a unique mode, i.e., the musical idiom is highly characteristic and very different from the diatonic scale of more recent music (see Pärtlas 1997; Pärtlas 2010; Ambrazevičius \& Pärtlas 2011). At the same time, the number of used melodies is limited. Group melodies are common (e.g., all harvest songs or travel songs are sung with the same melody). The Seto song is multipart and antiphonal. The lead singer, called sõnolinõ ('he/ she who knows the words'), says the verse that the choir repeats with variation 
and using polyphony. ${ }^{26}$ The special Seto multipart singing is based on the effect of the opposition of two voice parts. The Setos call the main melody and its singers torrõ ('good', 'nice') and the upper solo voice killõ ('sharp', 'shrill'). The torrõ part is usually heterophonic, though sometimes variations in the part are more planned, and then it is divided into 'torrõ' and 'lower torrõ'. The singer of killõ is expected to have a particularly loud, clear and rich singing voice so that it would stand out amongst the heterophony of the straggly torrõ part.

Killõ and torrõ in Seto songs are natural categories for the Setos. They are used to describe and measure also other polyphonic phenomena. In Siberia as well as in the Seto region in Estonia, it is common that the sopranos of Orthodox church choirs are called killõs. Although religious songs and Seto music are quite different in structure, as are the musical functions of soprano and killo parts (one is the melody voice and the other the accompanying voice, etc.), the same word is used to describe the two due to certain similar characteristics (it is the upper voice in a polyphonic choir, more intense than other voices, etc.). ${ }^{27}$ The Setos use the term killõ also for the upper voice in Russian songs. When singing Russian songs, the Setos seem to prefer a distinctive upper solo voice.

Maria V: Some sang killõ, and some sang torrõ. In the Russian songs too, one person sings killõ and others sing torrõ. It's the same in Seto songs, one woman sings killõ and others torrõ. (Khaidak village, July 2007)

When the choir of the Khaidak community house sang Russian songs, it was mostly only one woman who sang the upper voice. Apparently it was no coincidence that during the recording of songs in the Khaidak village in 2007 and 2008, Lidia K., the killõ of the older generation, always stopped singing the upper voice as soon as a younger woman took over, the part in the middle of the song, most probably because she did not wish to depart from the tradition that the upper voice is sung as solo part.

Here is another example, which proves that killõ and torrõ are natural categories for the Setos that are used to describe other similar phenomena. Olga M. was telling us about wolves, how differently they howl, and described their polyphonic howling. Some are killõs and some are torrõs, Olga said, and imitated their howling.

Olga M: When wolves howl, then one sings torrõ, the other killõ.

Andreas K: Is that so?

Olga M: Yes, they sing exactly like humans, one starts with a low wooww$w w$, the other repeats aayy-yy like killo. When there are four or five of them, they all howl as if singing, asking God to give them food. Asking where they are allowed to go. You shouldn't listen to those scabrous animals. (Khaidak village, August 2008) 
The area where the Setos had settled in Siberia was also inhabited by Protestant Estonians, who had emigrated from southern Estonia, constituted a majority in some villages, and soon assimilated among the Setos. Even though these emigrants spoke south-Estonian dialects, which are very similar to the Seto language, their music is very different from Seto songs (see Example 2). The Setos learned from them 'Estonian songs', the songs of the so-called newer singing style, which became popular in Estonia in the second half of the 19th century. The newer songs are end-rhymed and stanzaic, mostly sentimental ballads of borrowed origin (see Oras 2012; Rüütel 2012; Korb \& Peebo 1995). The melodies are not group melodies, like they are in Seto songs, but are associated with a specific text and are often of German or Russian origin. In the Estonian tradition, the songs were monophonic, but the Setos in Siberia sing them using polyphony, which is based mainly on Russian newer tradition (and the 19th-century Western music). Some of the sentimental songs sung by the Setos are also in the Estonian language. Siberian Setos do not usually speak Estonian, and thus the texts of these songs are often grammatically incorrect and obscure. Most of the newer Estonian songs known in Khaidak village are said to have come from Maria O.'s mother, and have been included in the repertoire of the community house choir through the mediation of her daughter. ${ }^{28}$

Besides Seto and Estonian songs, the repertoire of Siberian Setos also includes Russian songs (see Example 3). These are from different periods and of different origin: mostly popular songs from movies and the public media, local popular songs, and the approved repertoire of singing groups organised at community houses, learned through the mediation of cultural workers from songbooks published for the community houses or transmitted as oral lore (cf. Olson \& Adonyeva 2012: 134-135). People recall that many Russian songs have reached the villages through their relatives living in towns and cities. Maria P., for example, remembered that she learned the folk song Ia vstretil rozu ('I met a rose'; see Example 3) at family feasts in the Imbezh settlement, from her sisters who lived in Krasnoyarsk.

Maria P: Khoroshaia roza, semnadtsat' let ['Good rose, seventeen years']! Russian songs are all learned from the city anyway. My sisters used to visit us here, in Imbezh. They sang this Ia vstretil rozu, and so we started to sing it. The city people who had once left the village were visiting us in Imbezh. I wrote the songs down and we started to sing them. (Khaidak village, July 2007)

Most of the Russian songs in the repertoire of the community house choir come from younger women who also sing in the Russian choir of the Imbezh community house. 


\section{ON THE MEANING OF THE SONGS}

It cannot escape notice that among the Setos, groups of singers and the audience listen very attentively to the lyrics of Seto or Estonian songs and often discuss the meaning of the song after hearing it. More interesting or well-worded verses are repeated and admired; the audience wipe their eyes or laugh. The same happened only once or twice after Russian songs were performed. It is possible that Russian songs were considered to be commonly understood and thus their contents were not commented upon. It may also be that Russian songs are clearly perceived as 'songs', pure art, and are therefore considered less topical than Estonian or Seto songs, or less related to current affairs than, for example, Seto improvisations.

The new songs that the women sang with me were also discussed, and the most important verses were paraphrased in subsequent conversations. In 2007, I taught the women singing in the Lill choir a well-known Seto song about a moose killer. After singing it for the first time, the women kept saying, "Just think of it - he killed the moose!", and "I can't get it out of my mind how the moose fell down".

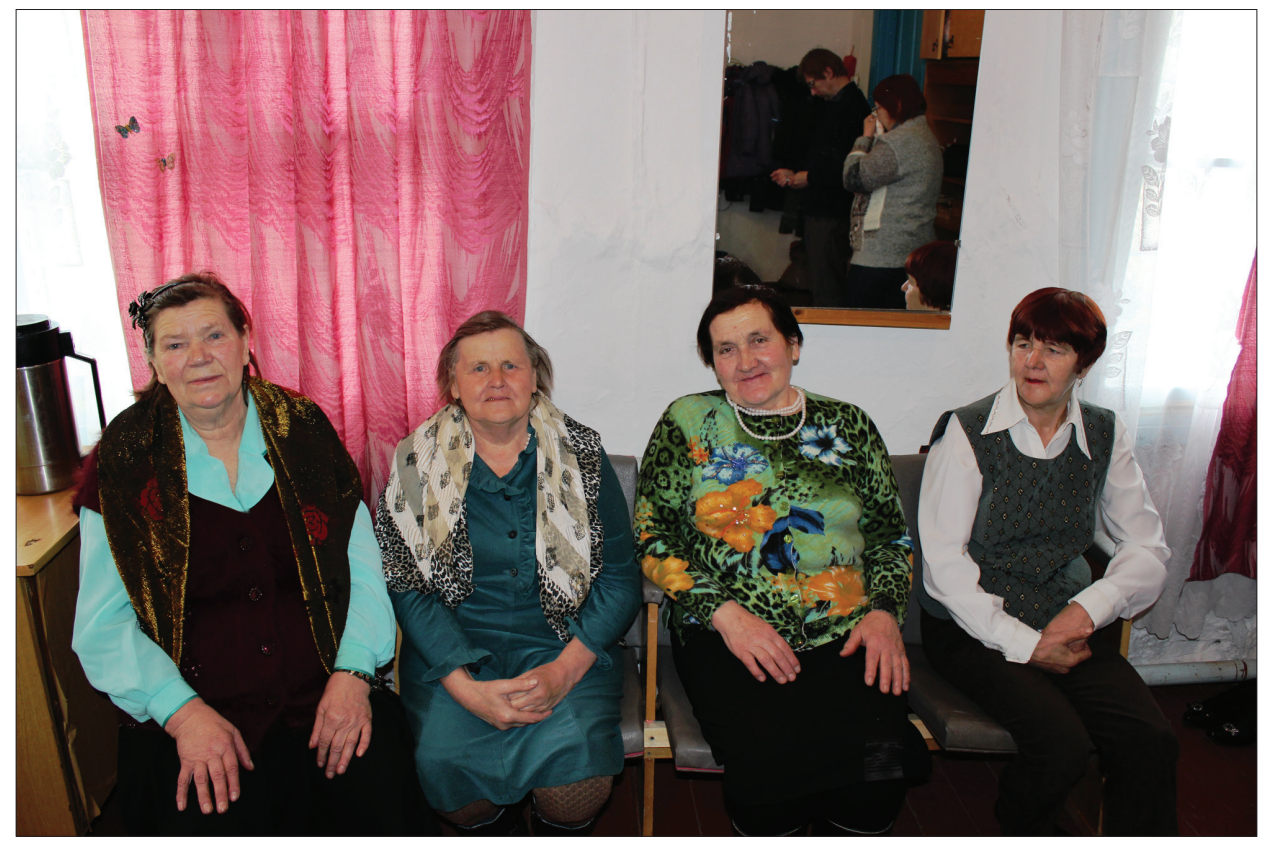

Figure 2. Community House of Khaidak village. Women before the recording of songs: Lidia Kondratieva, Maria Peterson, Maria Osipova, Lidia Ponomarchuk. Photograph by Andreas Kalkun 2012. 
The well-known Tütärlapsed, linnukesed ('Young girls, small birds'), an Estonian folk song of transitional form ${ }^{29}$, which contains several runo song motifs and is performed as a game song despite its rather tragic message, is known and loved in both Khaidak and Krestyanskii villages. The Setos in Siberia sing it in the south-Estonian dialect, so that the text is understood by everyone, unlike some other Estonian songs in transitional or even more recent form. In the song, young girls are warned against marrying a drunk, because a drunk beats his wife and children. The variants of the song sung by the Krestyanskii women and by Semyon's Olga end with a runo song motif, in which a woman is criticising her parents for not drowning her when she was a child. In 2007, during our first meeting with the Lill choir, the song prompted a dialogue, in which Alidia S. was surprised by the song's message, which advises girls against getting married.

Alidia S: Look, it says don't get married, but how can you not get married?! Maria O: Don't marry a drunk, a thug or a sluggard!

Alidia S: But how do you know if he turns out lazy or what he's like?! (Khaidak village, July 2007)

The Estonian song Üks rikka isa poeg ('Son of a wealthy man'), which Maria O. had learned from her mother, is most likely based on some north-Estonian text. While by now the song has been adapted to the south-Estonian dialect, it is still sung with several grammatical errors and inconsistencies. Some clearly north-Estonian forms have been contorted into the south-Estonian dialect, and vocal harmony has been added to the song. At the same time, some words representative of the north-Estonian language, such as nua instead of the Seto noun väidse ('knife') and südämes instead of the Seto süämeh ('in the heart') have been preserved. Regardless of the uneven text, the song's meaning is understood and the tragic story is found very touching. Our 2008 fieldwork revealed that the younger singers, who very likely might have a problem understanding all the Estonian and Seto song texts, are also fond of the tragic tale. For example, Tatiana M. requested that Maria O. sing specifically this song, "as it is so sad", and the performance elicited a conversation which demonstrated how the older generation of singers were emotionally moved by the song. At one point, though, they stopped delving into the sad storyline and abruptly changed the topic, as if wishing to get rid of such gloomy images, and proposed that we would sing something as well.

Lidia K: Is it over now?

Maria O: That's all!

Lidia K: What a sad song, isn't it?

Maria O: And you can't leave it unfinished. 
Lidia K: The groom also killed himself!

Maria O: They loved each other - the bride was poor, the groom was rich, and his father would not let him.

Lidia K: Well yes, so the groom fainted when the bride was lowered into the grave. Of course! Enough now! You sing now, we want to hear you sing! Sing us something, please!

(Khaidak village, July 2007)

Similarly, some songs reminded the singers of certain specific narratives that have probably been told among the group over and over. For example, after performing the song Mis nutad, minu süda? ('Why are you weeping, my heart?') Maria O. decided to mention that it was her grandmother's song about the time when young men were recruited into the army for 25 years. When her grandfather $\mathrm{O}$. had gone off to war, his future wife was still in the cradle and the "old O." had given the child two pieces of candy, saying that when he returned, he would marry her. And so it had happened.

Some songs triggered memories of earlier performance situations. For example, in 2008, after Olga M. and Maria V. had finished singing an obscene song in Seto style about a hare startling a young maiden in the field, Maria V. admitted that she had almost forgotten the song and had remembered it only upon our request to sing it in 2007. Olga M., in turn, then recalled how they had once sung the song when they came back from the funeral of a woman called Hilda. Upon that, Maria V. remembered another time when they had sung it when returning from making silage. ${ }^{30}$

It is also very typical that singers remember the person who preferred to perform a particular song. Olga M., for example, associated several songs with specific people. She seemed to find the performances by men particularly remarkable: for example, after singing a song to the tune of a men's song, she mentioned it was performed by Turbin's Hilip. Also, when trying to recall a newer south-Estonian drinking song, Ma olen oma isa üksainukene vara ('I am my father's most precious treasure'), Olga M. spoke about the performance of a man called Kiisla's Timmo. Timmo had died already 50 years before, but the song always reminded Olga $M$. of his performance.

Olga M: Late Turbin's Hilip used to sing this song!

Maria V: Which song?

Olga M: Setokõnõ ['Seto']. You could sing the song until the next morning!

Maria V: You just had to 'pick' the words, from wherever you could.

Olga M: We had an aunt called Aleksandra, she could pick up any song at a wedding and keep on adding words until the end of the festivities.

She had many words. 
Maria V: Maria O.'s mother also had many words. Once we spent the night at her house, and she kept singing with the same melody the whole night, adding words about everything!

(Khaidak village, August 2008)

\section{SONGS AND ‘NON-SONGS’}

When singing Russian and Estonian songs, the women of the Khaidak village found it very important that none of the verses that were traditionally sung would be skipped during the performance. When a performer happened to skip a verse or a line, an apology was due. At a singing event, the older women of the Lill choir were displeased that Anna K., a younger singer, had left out a few known verses from a Russian song. So, when Anna finished the song, Lidia K. voiced her disapproval and sang the missing verse. After her, Maria P. sung another verse and Anna K. apologised for having skipped it. ${ }^{31}$

Apologising for skipping a verse or a line was also very common when newer Estonian songs or those of a transitional form were sung. Once, when Olga M., the singer who had the largest repertoire among the older generation, performed the game song Tütörlapsed, linnukesed ('Young girls, small birds') as a solo song, she found it necessary to apologise for leaving out a line or two. Suddenly, Maria V.'s husband Mikhail V. intervened in the conversation and snapped at the women, shouting that they should not sing it at all if they did not know the words, upon which his wife sang the previously left out verses.

Olga M: I'm already starting to forget the beginning. I need to hum a little sometimes. Now I'm not even going herding anymore.

Mikhail V: You've left out half the song. If you can't sing, don't do it at all!

Olga M: Come, help me with the lead!

Maria V: "Baked bread from alder leaves, made porridge from willow bark."

Olga M: Oh, I have forgotten all that!

(Khaidak village, August 2008)

The interviewed Seto women in Siberia were often quick to name the Estonian and Russian songs they knew, but became confused when asked to talk about Seto songs. Since improvisation was often the first thing that came to their minds when talking about Seto songs, they agreed that the songs were rather obscure, saying that "those who can, sing about what they see or what comes to their mind". When referring to Seto songs, Siberian Setos used words related to the natural, commonplace or trivial. For example, in 2007, Nadezhda 
K. (b. 1937) and Anna M. (b. 1938) from Bulatnovka discussed Seto, Estonian and Russian songs. The conversation revealed that Nadezhda's mother was a Seto - as is often the case among Siberian Setos, she apologetically added that they were not "real Estonians, but Setos" - and liked to sing Estonian songs. A question about Seto songs, however, confused the women. Nadezhda K. said that Estonians as if had their songs, but the Setos did not, they sochinyali, ${ }^{32}$ sang about what they saw around them. The women found the melodies of Seto songs quite commonplace and ordinary, claiming that there was no special melody to them, simply singing. ${ }^{33}$

Andreas K: So your mother was a great singer?

Nadezhda K: Yes, my mother could sing all the Estonian songs. She wasn't pure Estonian, she was a Seto, but knew all the Estonian songs. They sang beautifully. My sister too, they knew the songs very well.

Andreas K: But could she sing Seto songs as well?

Nadezhda K: There aren't many of these Seto songs, there are only Estonian songs. When singing a Seto song, one sochinyaet, improvises about what she sees, sings the lead. But Estonian songs were different.

Andreas K: What were the Seto melodies like?

Nadezhda K: There was no melody or anything, just singing. Estonian songs have words that are taken straight from real life. They sang about how life used to be. The Estonian songs were very good.

(Bulatnovka village, July 2007)

When we first met the Khaidak village choir in 2007, Maria P. welcomed us with an improvisation to demonstrate what a 'real' Seto song was like. A Seto improvisation always reflects the audience and the performance context, so all members of our fieldwork team - Anu Korb, Marge Laast and me - were put in the song.

\section{Maria P:}

Eestist tulliva’ külälise’.

Tops õks viidi, tõnõ tuudi, katsipooli kannõti.

Anukõnõ, tsidśakõnõ,

Margo, meelimaŕakõnõ,

Andreas, kuku velekene!

Sedä-ks aigo ammu oodi, ammu-ks oodi, kavva kai.

[We have guests from Estonia

A cup was taken away, 
Another put on the table,

Carried by two men.

Dear Anu, my sister,

Margo, my beautiful,

Andreas, dear brother!

We have long been waiting for this moment

Long been waiting, long expecting.]

(Khaidak village, July 2007)

We had a similar encounter during the 2008 fieldwork. This time, Olga M., who represents the older generation of singers and had never sung in an official choir but was known for her brilliant singing skills, was also present. Maria P., who was eager to have us experience the 'real' Seto song, asked Olga M. to show how Seto singers sing about what they see and think; for example, with a dedication song to me and Anu Korb. The elderly woman at first did not understand what was asked of her, but then sang an improvisation to the guests employing the Tulevik teadmata ('Future unknown') and other runo song motifs. ${ }^{34}$ However, Maria P. was not quite content with the song, because it was too poetic and not specific enough, and asked Olga M. to create a song about, for example, how Andreas and Anu took a plane to Krasnoyarsk, then from there a bus to Khaidak and then walked to Bulatnovka village. ${ }^{35}$ Maria P. considered it necessary to tell us about the spontaneity of Seto songs and their relation to time and place even after an Estonian song was performed.

Maria P: Well, Seto people also have this thing - that I just saw you and I'm going to sing about you right now. A Russian or an Estonian song has to be sung the way they are, but this is how we do it: for example, I saw you, and now I will sing about it. [...] What you are like determines the song. (Khaidak village, July 2007)

Discussions about the "real" Seto song often evoked memories about singing at weddings. Praising or taunting someone at a wedding was given as an example of the flexibility and improvisational nature of the Seto song. Lidia K., killõ of the Lill choir, also differentiated between a 'proper' song and spontaneous improvisation. The wedding lament is an example of an improvised Seto song.

Andreas K: And this was also a wedding song?

Lidia K: It was simply sung anywhere, in village streets. This one was a real song, but the wedding laments and other such are improvised with own words. In the old days there were many people who could do this, but nowadays there are not many who can create these real Seto songs. (Khaidak village, August 2008) 
While Seto songs were generally characterised as being made up, often using the Russian verb sochinit', Russian and Estonian songs are known to be fixed, sung correctly, po poriadku. Compared to other singing styles, Seto songs were also typically seen as very long, endless and amorphous.

Maria O: But these Estonian songs are indeed long. Very long. When you start singing a Seto song, for example, Mari-sori, which is a very dirty song, you start singing it in the evening and you can keep singing until the next morning. It's very long!

Lidia K: But that song is not improvised, it's sung po poriadku. (Khaidak village, July 2007)

Vasili K: You see, a Seto song never ends; you keep looking around and sing on!

Lidia K: Yes, but then you need someone who knows the words, who sings the lead. When I start singing the lead and the choir joins in and starts interfering, I get it all mixed up.

(Khaidak village, July 2007)

Aside from that, other figures of speech were used to characterise the length and unique creative process of a Seto song. Olga M., for example, talked about the length of her herding song and how the text was not fixed, claiming that she simply had to 'pick' the words when singing.

Andreas K: But when you are with the herd, what do you do then? Do you hoot as well?

Olga M: No, I don't hoot, there I'm singing the herding song for a while.

Andreas K: What's the herding song like?

Olga M: The herding song? It's long, however you want to sing it, you pick the words.

Andreas K: But how?

Olga M: I simply start picking.

(Khaidak village, August 2008)

I found quite similar comments and metaphors about creating the Seto song in the recordings made in the villages at the end of the 1980s. The women of the Khaidak village performed to the folklore collectors (Igor Tõnurist, Mare Piho, and Õie Sarv) an improvisation to a men's tune and the lead singer and a member of the chorus then discussed the idiosyncrasy of the Seto singing style. Again, the informants emphasised that the Seto song was not a ready-made song to be repeated over and over again, but that a proficient singer could continue the song almost indefinitely. 
A: That's enough!

B: It is like whenever you know the word, you just say it!

A: It's not specifically that you sing like this...

B: ... or continue like that... it's how the singer says it.

A: When you pick up the song, it never ends.

B: A Seto song knows no bounds.

(Khaidak village, September 1987)

The improvisational nature of the Seto song and the possibility of endlessly creating the song was also discussed after the performance of a mock wedding lament. The singer disrupted the song and expressed regret, saying: "It does go on, but that's all I can remember". Upon that, a co-singer, who evidently hoped it would not continue, made a derisive comment, "Hasn't the song already lasted for a week?"36

\section{IMPROVISATION IN THE SETO SONG: PERIPHERY OR CORE OF THE TRADITION?}

In the early history of Estonian folklore studies, cultural heritage was often approached as something homogeneous and ready-made, waiting to be collected. At the same time, little thought was given to how the heritage had been constructed and created ${ }^{37}$ and which ideologies and politics it had supported. Our contemporary views of the Seto singing tradition are largely based on what collectors, publishers and researchers of Seto songs have once created. Immediate fieldwork experience, however, may reveal how simplified and stagnant this knowledge is and how the songs recorded, stored in the archives and published in anthologies represent only a small selection compared to the variability, dynamicity, divergence and ambiguity of the living tradition. Texts constructed by researchers, fitted to genres, and isolated from the context and performance, give only a vague idea of what live performance could have been like (see Bauman 1988 [1986]: 3ff.; Briggs 1988: 353ff.). A researcher's and a performer's understanding of the tradition and its nature, salience and value are often widely different.

The interviews conducted with the Setos in the diaspora revealed a radical emphasis on the improvisational nature of the older singing culture. The Seto song was characterised as something highly natural or spontaneous, created on the spot. At the same time, the unique improvisational nature of the song led many to regard the singing style as something commonplace or insignificant compared to Russian or Estonian songs. Many of my informants admitted that 
they did not consider the Seto song a 'proper' song. The choir of the Khaidak community house preferred to sing Seto songs outside formal performance situations: for example, at the choir's formal performances in 2012 these songs were not performed, but they were sung later in more informal situations, while sitting together at dinner table.

Seto improvisations are typical in that they deal with current or autobiographical matters. Researchers searching for ancient songs that would conform to established type ${ }^{38}$ have regarded them less valuable than the songs in which the aspect of 'creation' is overshadowed by 'recollection' or 'mediation'. ${ }^{9}$ Folklorists have thus preferred to collect songs in which the performer mediates the old tradition and in which his or her own person and creative nature remains hidden. Regardless of the speculations and errors of researchers, the Setos both in Siberia and Estonia have considered the skill of creating new songs and spontaneous improvisation one of the most important criteria for assessing a singer's creative ability and knowledge of the traditional singing style. ${ }^{40}$ One of the major events at the annual celebration of the Seto Kingdom Day $^{41}$ is the sõnolisõ contest, in which the best singers compete in creating the finest (i.e., the most topical, but at the same time the most traditional) song on a given topic within a given time (see Sarv 1997; Kuutma 2005: 230). In 2009, on the initiative of the Setos in Estonia, Seto polyphonic singing was inscribed on UNESCO's Representative List of the Intangible Cultural Heritage of Humanity. To be inscribed on the list, several Seto organisations cooperated in writing a comprehensive overview of the Seto singing tradition. Improvisational skills were mentioned already in the first introductory paragraph as a highly characteristic feature.

Seto leelo (literally 'song') denotes a traditional singing style, repertoire and culture of the Setos. Its poetic structure and certain musical features are estimated to date back a millennium. Its text and metrics present a local version of the Baltic-Finnic runo song tradition; leelo is characterised by an alternation of solo and choral parts. A lead singer performs a verse line; the choir joins in for the last syllables, and repeats the whole line. Based on their knowledge of traditional poetic formulae, the rules of the poetic and metric system, Seto lead singers create new lyrics for each particular occasion. They perform also texts learnt from previous great performers, but the skill to compose lyrics is essential for a renowned lead singer (Seto leelo 2009).

At the same time, modern Seto singing culture in Estonia reveals a tension between the fixed-form song and improvisation. Leaders of Seto choirs today accuse each other of reciprocal (often secret) recording of other choir's songs 
and learning the songs of 'others'. Great female singers intently listen to and 'recognise' their 'words' in the songs of other singers and are full of contempt towards the singers who do not have their own words and who compose songs by taking "one line from here, another from there". Some Seto choirs have even declared their refusal to sing "the songs of others", because they consider it immoral (see Laanemets 2012). ${ }^{42}$ Aside from that, contradictory preferences that value the fixed form could be observed. In the debates and discussions about the future of the Seto singing style, some Seto choirs have demanded that specific, highly valued songs, which are generally associated with specific singers, should "stay as they are", so that no one could "change and corrupt" them. Despite the fact that such popular songs have acquired a certain fixed form, because they are published on records and tapes, they are still known, in different versions, in orally transmitted folklore (see Kalkun 2011: 42). Indeed, while the younger generation of diasporic Seto singers value spontaneous improvisation as a skill, they also avoid practising it. Improvisations, they believe, are too commonplace, even vulgar, their texts too long and the melody uninteresting or lacking in musical qualities.

\section{TENTATIVE CONCLUSIONS: DISRUPTIONS AND CONTINUATIONS}

While ever since the 1920s, the Setos in Estonia have been taught that their song tradition is part of an ancient, valuable and authentic Baltic-Finnic song tradition, the Setos in the diaspora have lived in a completely different sphere of information and have not heard of the knowledge, accumulated by folklorists and used by the Setos in Estonia to strengthen their identity and culture. When local cultural workers and state-supported community houses started to provide minority groups with resources to perform their traditional songs, ${ }^{43}$ the generation who sang in the community house choir already had a rather vague idea about their tradition and its nature. They were more than willing to comply with the foreign cultural workers' wishes and present their 'authentic' singing tradition, but at the same time they had alienated from certain elements in their musical culture (its improvisational nature, ancient modes), which were particularly characteristic of the earlier part of the tradition. The conscious or subconscious wish to assimilate to the dominant singing culture on the one hand, and to present their own unique singing culture on the other, has created an interesting situation in Seto diaspora communities, in which hybrid forms emerge, which domesticate foreign elements and adapt genuine ones. Towards the end of the 1980s, modes characteristic of early Seto music (for traces of 
earlier modes, see the notation in Example 1) had become rarer owing to the influence of music in diatonic scale. ${ }^{44}$ The number of singers who know how to improvise song texts in the old style has fallen significantly. Improvised songs are not suitable for performing on stage; the community house choir, for example, prefers to perform songs they have sung many times to avoid any inaccuracies on stage. The early Seto singing tradition is thus represented in today's repertoire of the Khaidak village choir by newer rhymed songs with fixed texts, modified to the Seto culture, and with melodies of a broader scale and mostly borrowed origin.

The Seto singing style in Siberia is an interesting, yet odd, combination of stability and changeability, the old and the new. The songs and tunes of Estonians, Setos and Russians have merged into a unique whole. Younger generations

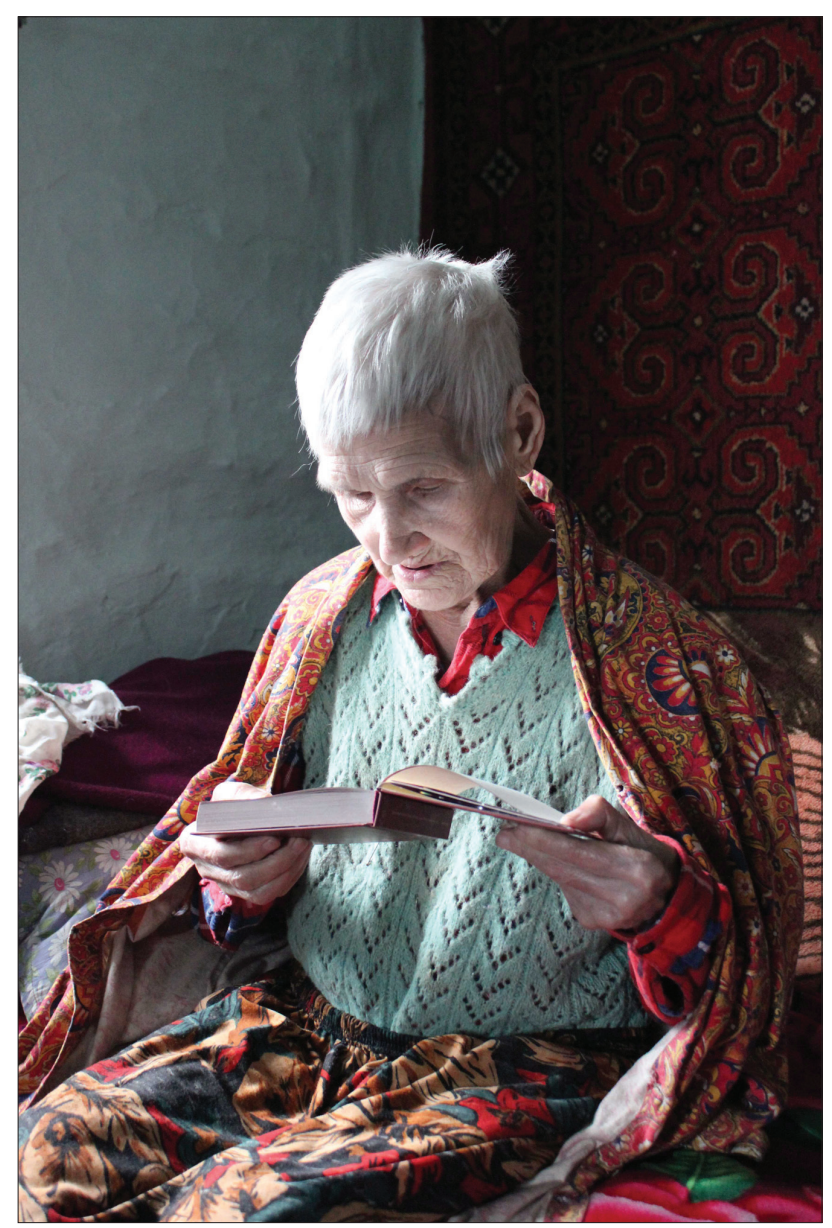

Figure 3. Maria Vasileva of the older generation of singers is examining the edition "Songs of Siberian Seto". Photograph by Andreas Kalkun 2012. 
re-interpret their song lore and issues related to identity. The singing tradition of the Setos in Siberia shows a clear disruption within the generation of the Soviet period, who felt uncomfortable singing songs in the Seto language in their youth. As the generation is aging and has found a new nostalgia towards their ethnic culture, but also as a response to encouragement from the outside to foster their own culture, they are developing a new consciousness of their ethnic group and its unique tradition.

As the communities of Seto villages in Siberia are becoming increasingly multi-ethnic and mixed marriages more commonplace, we can no longer speak about a homogeneous community based on an ethnicity or descent, but these are imaginary communities that modify and perform their ancient, though still existing tradition (see Anderson 1994 [1983]). The new generations of Seto singers in these Siberian villages adapt the singing culture to fit their needs and redefine the tradition based on their views of what is 'proper' music and song. The fact that the line drawn between songs and 'non-songs' in contemporary Seto singing community in Siberia leaves the earlier part of the tradition to the category of 'non-songs' is probably caused by the disruption inside the culture, but also by the endeavours of cultural workers and the need to present own culture on stage.

Despite the fact that the Seto singing tradition has lost its ancient ritual functions and its most unique part has been marginalised among the Seto communities in Siberia, even the singing, which today is increasingly mainly heard in community houses and museums, serves a function of supporting identity and symbolically constructing the community (see Tarkka 2005: 388). In this light, as long as these women keep on singing what they call the 'Seto song', in whatever form, in the community house or at private gatherings, they continue to fulfil a new ritual function - namely, constructing their cultural heritage and identity. Indeed, the concepts of 'Seto people' and 'Seto song' may entail different meanings at different times, but as long as there is still discussion about the nature of Seto songs and the categories of songs and non-songs, the efforts to forge one's identity and singing tradition continue.

The community of Seto singers in Siberia is tiny and very susceptible to external influences. During our fieldwork we experienced their immense interest in relatives living in Estonia and their songs. Many women whom I met in Siberia asked me to teach them songs that are sung in Estonia, and to send them recordings of Seto songs. Only time will tell how the Seto singing culture in Siberia can change after their songs are published. In 2012, the Estonian Folklore Archives published an anthology of Seto songs in Siberia (see Kalkun \& Korb 2012). When we introduced the anthology in Krasnoyarsk in 2012, the Khaidak village choir had increased by a couple of members, who in 2008 had 
told us that they did not know any Seto songs. By then, several older Seto singers had become bedridden and stopped singing. The future of songs and non-songs and those who sing them therefore remains to be seen.

\section{COMMENTS TO THE MUSICAL NOTES OF THE SONGS}

\section{Example 1. Seto song}

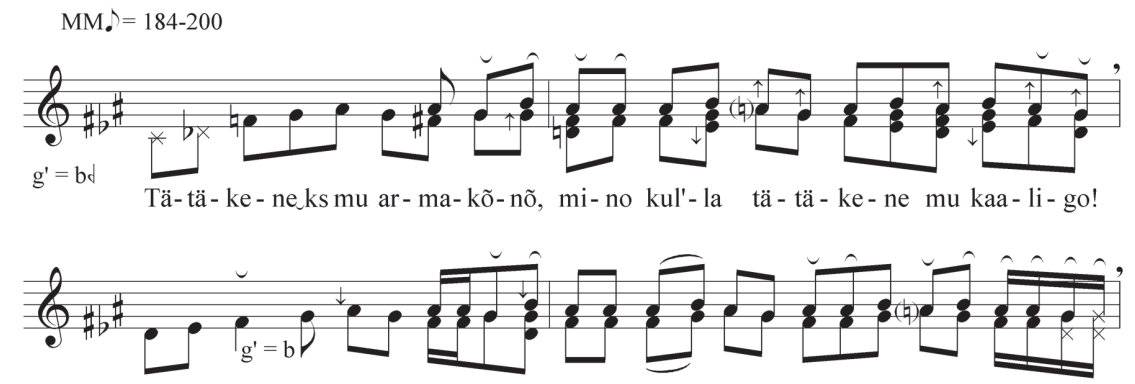

Sul- lõ_ks lää ma ma-no ma-r'a-kõ-nõ, sul- lõ lää tä-tä-ke-ne ma ma-no ma-r'a-kõ-nõ,
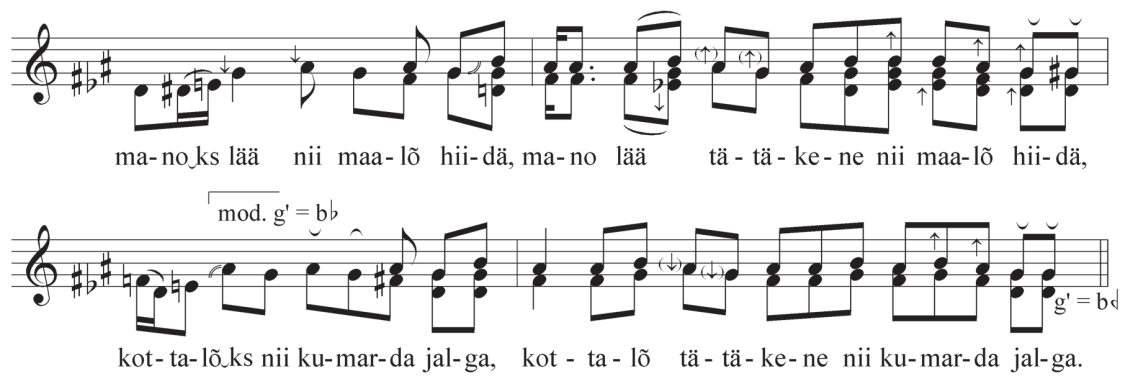

The bridal lament represents the earlier Seto multipart singing style. The bride traditionally sings the lead, while the chorus part is sung by podruskid, bridesmaids, in a bridal lament. The singing is accompanied by rhythmic bows. In the lament, the bride addresses her father, asking why she has been given 
away, while she is needed to plough the field. She fears that life in her husband's home will be hard, and contemplates whether she should drown herself instead.

The lament, recorded in 1988, is performed by elderly women in the Khaidak village choir. The notation presents the first four verses of the 34 -verse lament. The chorus reiterates the verse sung by the lead singer, inserting the address formula tätäkene ('dear father') in the middle of the verse. In the earlier Seto singing tradition, as in many Baltic-Finnic runo song regions, the chorus joins the lead singer before the end of the line, in this case, on the third to the last syllable. The end notes of the chorus part are generally lively and accelerated, and are followed by the lead singer with no pause in between. Typically to the songs of an earlier style, the syllabic melody is fitted to the text: the rhythm and melodic contour change according to the verse structure (e.g., the end of the chorus part varies, having 4-7 syllables after the added addressing formula).

In musical terms, the unique feature of the most archaic Seto tunes is a rare scale, in which semitone intervals alternate with three semitone intervals (D-Eb-F\#-G-A\#-B). The harmonic system is based on two opposed complexes of scale notes, consisting of four-semitone intervals (D-F\#-A\# and Eb-G-B) (e.g., Pärtlas 2010; Ambrazevičius \& Pärtlas 2011). Here the upper solo part killõ uses the three upper notes of the scale, while the lower torrõ part is sung heterophonically and up to three notes may be sung simultaneously. The performance reveals the tendency of singing the second tone of the scale (Eb) at a lower pitch and, regardless of the harmony, the lower note usually sounds approximately like $\mathrm{D}$, which has also been noticed in the performances of some other Seto choirs (e.g., Ambrazevičius \& Pärtlas 2011: 4; Särg 2012). The lament is sung using the chest voice in the speech register, and the pitch of scale notes varies considerably. During the singing, the pitch gradually rises, and the marking mode indicates a typical device in Seto singing called kergütamine ('facilitation') - an abrupt modulation by lowering the pitch about a semitone. The additional markings $\smile$ and $\neg$ show slight shortening and lengthening of the note (sometimes depending on the syllable length), while $\uparrow$ and $\downarrow$ show the raising or lowering the note by less than a semitone. 


\section{Example 2. Estonian song}

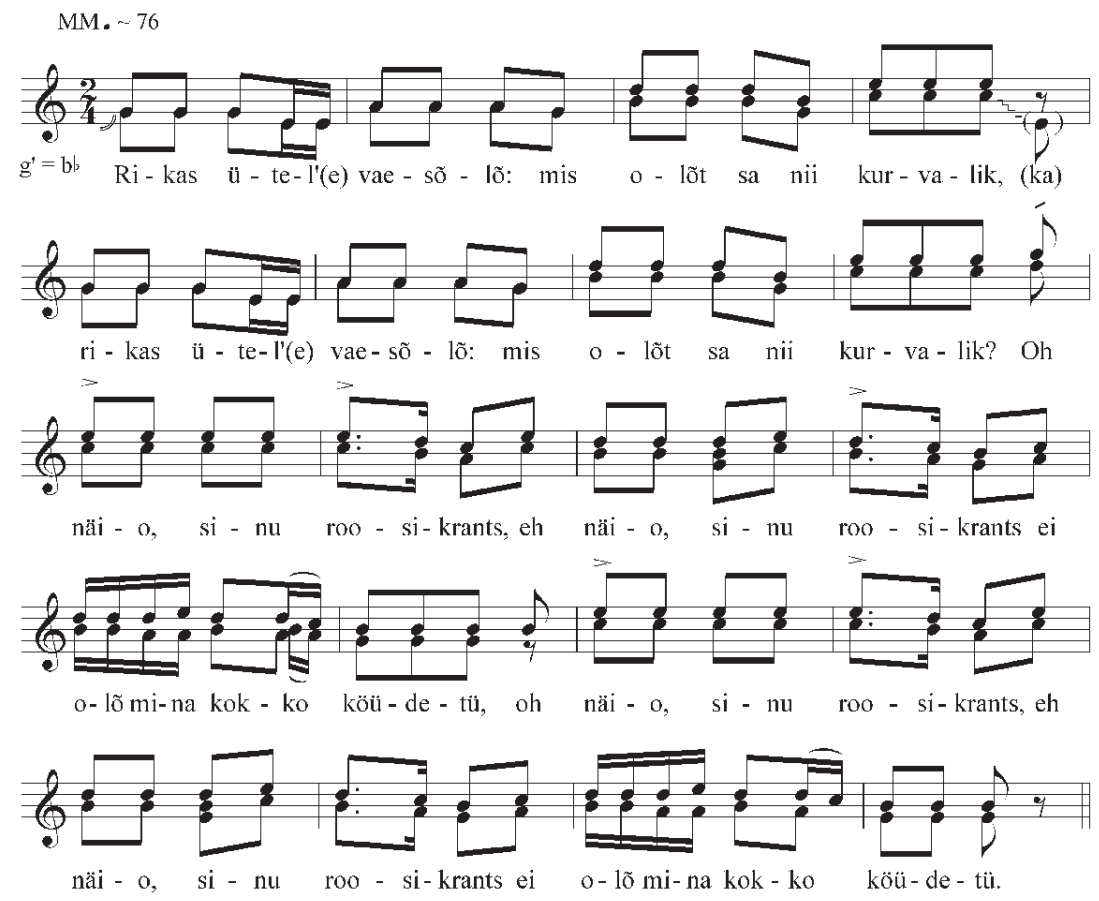

The Estonian love song represents the so-called newer, end-rhymed and stanzaic singing style, which became very popular in Estonia at the end of the 19th century. In the song, performed in 2007 by the Khaidak village choir, two maidens discover that they are in love with the same young man. The man decides to give them both up and chooses a third girl. In Estonia, the song is known in the areas neighbouring the Seto region as a game song. The song's content is acted out, or singers walk in a circle and dance during the chorus Oh neiu, sinu roosikrants ('Oh, maiden, your chaplet of roses') (see Rüütel 1983: 128-135).

The notation features the second verse and the refrain of the 7-verse song. The song is sung in chorus without a lead part, as is characteristic of newer Estonian and Seto singing styles. The upper solo voice, which functions as the accompanying voice, splits from the lead voice in the verse part in the middle of 
the line. While singing in the earlier and newer style in the Estonian tradition is mostly monophonic, this performance demonstrates a stable multipart singing. The dominant movement is in parallel thirds, which matches the functional harmony characteristic of the style. Comparison of this Seto version with the melody known in Estonia reveals that in this version the melody is sung by the lower voice, while in the refrain part the main melody is sung by the upper voice (although the Estonian song's tune ends with a descent D-C-B-A-G). Such multipart rendition may be explained with an aim to follow the harmony of the melody.

It is notable that the cadences of the Estonian and Russian song (Example 3) are different from each other. While Russian songs typically have the cadence in a unison or octave, the Estonian song has a major third in the cadence. In this Seto version, the use of the third in the cadence can be linked to the earlier Seto multipart singing style. Such imperfect cadence is also characteristic of songs of Estonian emigrants in Siberia, in which a unique kind of multipart singing has developed under the impact of the Russian tradition (cf. Pärtlas 1995).

\section{Example 3. Russian song}

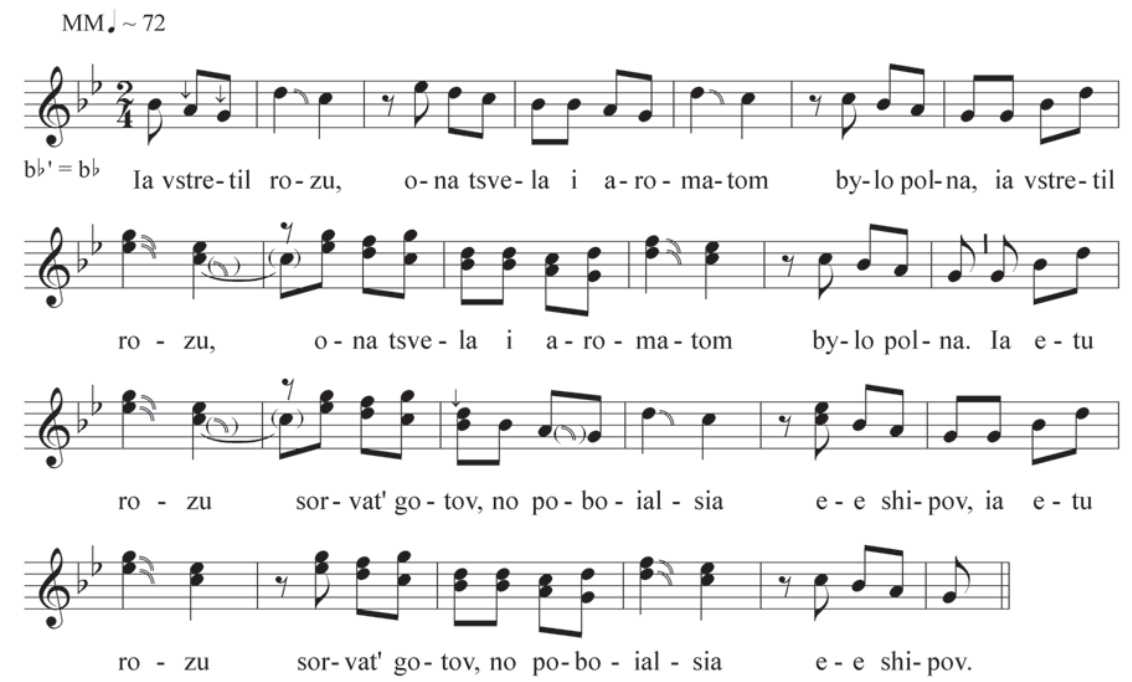


The song in the Russian language represents a newer Russian urban song style and was recorded in 2007 from the Khaidak village choir. The song is built upon the imagery of rose. The singer dares not to touch the rose, but others strip it of its beauty. In the end, young men are advised not to touch 17-yearold roses. This song may originate from the 1960s-1970s, according to online song anthologies (see a-pesni; Antologiia; Dvorovye romansy). The performers learned the song from one of the singer's relatives who lives in town.

The notation presents two verses of the 6-verse song. The song is sung in chorus, the lower main voice is joined by an upper accompanying voice sung by one singer. It is difficult to distinguish whether the accompanying voice occasionally joins in the unison or makes a pause in singing. The version of Khaidak women is distinct in that from the beginning of the second verse they only repeat the latter half of the melody. The song is typical for the newer urban song style, in which Western influences are combined with specific features of the 'Russian style', such as the natural minor, plagality and the characteristic multipart singing (e.g., Shchurov 2007: 276-279).

\section{ACKNOWLEDGEMENTS}

The study is carried out within the framework of the research project IUT22-4, "Folklore in the Process of Cultural Communication: Ideologies and Communities", financed by the Estonian Ministry of Science and Education.

\section{NOTES}

1 The notations of the songs and comments are by Janika Oras, who also participated in writing the chapter 'Three singing styles'. We would also like to thank ethnomusicologist Žanna Pärtlas for her suggestions regarding Russian singing tradition.

${ }^{2}$ Khaidak village choir, audio tape recorded by Igor Tõnurist, September 1987.

3 Andreas Kalkun participated in field expeditions to the Seto villages in Krasnoyarsk Krai, organised by the Estonian Folklore Archives, in 2007, 2008 and 2012. The fieldwork covered the largest Seto villages in the diaspora, Khaidak and Novaya Pechora, but also much smaller villages and settlements with Seto population (Bulatnovka, Krestyanskii, Kiyai, Ostrovki, Narva, Partizansk) in the Partizanskii, Manskii and Rybinskii districts and the city of Krasnoyarsk. Khaidak village in the Partizanskii district has the largest Seto population, among whom the cultural heritage has been preserved the longest. Anu Korb, folklore researcher at the Estonian Folklore Archives, was his main fieldwork partner; in 2007 they were accompanied by Marge Laast, in 2008 by Tiit Sibul and Astrid Tuisk, and in 2012 by Eva Sepping and Vahur Laiapea. 
4 The language spoken in the Seto region has been identified as the eastern variety of Võro dialect (e.g. Keem 1997) and as a separate dialect (Pajusalu 2000; Pajusalu et al. 2009). Be that as it may, the Seto language shares common features with the eastern group of the Võro language (Keem 1997; Keem \& Käsi 2002). The Setos themselves claim that they speak the Seto language and find it different from the varieties spoken elsewhere in southern Estonia. When the Seto language is treated as a variety of the Võro language, the Setos in Estonia often take it as an insult or a threat to their linguistic autonomy (Juhkason et al. 2012). This is the reason why henceforth I have chosen to use the term 'Seto language' in the article. Also, I prefer to use the ethnonym 'Seto' instead of the form 'Setu', which is common in standard Estonian, since the Setos themselves consider the latter a disparaging term.

5 Estonian song tradition has also been characterised by the fact that the performers have not considered the melodies of earlier type as proper tunes or distinguished between them (see Rüütel 1998).

${ }^{6}$ Derived from the Russian word for Russia (Rossiia).

7 This confusion regarding ethnic identity has been observed also among other groups that have migrated to Siberia. For example, the Protestant Prussians, who had emigrated to Poland (the present-day territory of Ukraine) in the 17th century, had adopted the Polish language by the 18th century, and had migrated to the vicinity of Irkutsk in Siberia in the early 20th century, refer to themselves as the Dutch (see Muszkalska \& Polak 2009).

8 Igor Tõnurist took part in the field expeditions organised by Mare Piho, an ethnologist with Seto roots, with the Estonian National Museum. Õie Sarv, also of Seto origin, participated in the expedition of 1988.

9 The exact number of emigrants is unknown, but August Nigol (1918: 55), who has studied Estonian settlements abroad, claims that over 5,000 Setos settled in Siberia.

${ }^{10}$ Before the ethnic identification eestlased was more widely adopted, Estonians also used to refer to themselves as 'countryfolk' or 'countrymen' (see Kuutma 2006: 169).

${ }^{11}$ On the folklorists' particular preference of men's songs in this period, see Kalkun 2011: 141.

12 The same held true for Seto choirs in Estonia (see Kalkun 2004). While by the 1990s village folk groups also elsewhere in the Russian Federation were predominantly allfemale, some men sang in women's groups only in the Cossacks' and Old Believers' regions (see Olson \& Adonyeva 2012: 137).

${ }^{13}$ I have also studied social groups of Seto women singing in folk and church choirs, with a focus on interpersonal relations and conflicts in these groups stemming from different preferences of song styles, etc. (see Kalkun 2004; Kalkun \& Ojamaa 2009). More recently, Liisi Laanemets (2012) has studied a choir with Seto roots, active in the city, and its identity performance.

14 The majority of songs that were collected during fieldwork come from Khaidak village. There are certainly singers elsewhere as well; for example, in 2007 the women of Krestyanskii village came together upon our wish and recalled and sang their songs. 
${ }^{15}$ In this article I refer to all my informants by the first name and the initial of the surname. The ages of the informants are given in parentheses at first mention. The choir leaders were Maria O. (b. 1942), Maria P. (1941-2013) and Lidia K. (b. 1939). During the recording sessions of 2007, one of the singers who happened to sing to us was Alidia S. (b. 1943), who had become a permanent member of the choir in 2012, when the choir's core had become smaller.

16 The singers junior to the leading trio, Anna K. (b. 1952) and Tatyana M. (b. 1961), represent the younger generation of Seto singers in this article.

${ }^{17}$ Of the three leaders of the choir, one married a local Estonian, others married Seto men. Only one of the children of the core group women is still living in the village, others have moved elsewhere, to larger cities and settlements. All of their children have married Russians.

${ }^{18}$ All sample interviews were originally in the Seto language. The texts were transcribed from video and sound recordings. The recordings made by Igor Tõnurist and the material collected and recorded by us in 2007, 2008 and 2012 are kept in the Estonian Folklore Archives. Henceforth in this article references to the recorded material include the name of the village and date of recording.

${ }^{19}$ During our fieldwork we experienced on a number of occasions the older singers' willingness to improvise songs in any situation, and indeed, they could break into singing in the most unexpected places. For instance, Olga M. performed an improvised farewell song in a dark car full of people when driving home after a party at the community house. Lidia K., who was also in the car, asked the driver to first take Olga M. home, so that she would not miss the song. Another time, when we had packed our recording equipment after an interview and recording of songs that had taken a couple of hours, our hostess and her guest started singing an improvised dedication and farewell song.

${ }^{20}$ Representatives of the older generation of singers in this article are Maria V. (b. 1927) and Olga M. (b. 1932). The latter, while being close in age to the women singing in the choir, represented the older generation in terms of lifestyle, poorer command of Russian and singing style.

${ }^{21}$ According to an old tradition, which dates back to the time before the Setos were given family names, it is still customary in Seto villages in Siberia to call people by the name of their father, grandfather, mother, brother or village. Semmeni Olli means Semyon's Olga, in this case, Olga, Semyon's daughter.

${ }^{22}$ According to the Setos in Siberia, the first exile generation married only inside the ethnic group. The next generation showed some marriages with Lutheran Estonians, and by the present day the nationality or language is no longer relevant when choosing a partner in life. This may also explain the preferences of Estonian- or Russianlanguage songs in certain periods of time.

${ }^{23}$ The sound tapes with material recorded in 1987 and 1988 by ethnologist Igor Tõnurist are the only known song recordings from these villages until our fieldwork in the late 2000 s. There is also a small amount of material, including singing, recorded on VHS tapes by the local villagers at the end of the 1990 s.

${ }^{24}$ On the historical principles of selection of recording songs, see, e.g., Kalkun 2011; Oras 2008; 2009; also Kallio 2013: 332; Timonen 2004: 13ff. 
${ }^{25}$ In popular Seto terminology, a 'word' may stand either for a single word or a smaller unit within the song (verse-internal formula, verse, parallel word pair or a broader unit, such as a 'motif' or 'type', commonly used among folklorists). See also Virtanen $1981 ; 1987 ; 1994$.

${ }^{26}$ However, it is typical of the older songs sung most often by the community house choir that the lead singer does not sing along for long and the choir joins in as soon as they recognise the verse.

${ }^{27}$ See Kalkun \& Ojamaa 2009.

${ }^{28}$ During our first fieldwork trip in 2007, Maria O.'s mother was still alive, but we had no chance to meet her. Unfortunately, by our 2008 fieldwork, she had already passed away.

${ }^{29}$ In Estonian folk music, the transitional form is characterised by the combining of elements of earlier regilaul songs and the poetry of newer end-rhymed songs (see Rüütel 2012).

${ }^{30}$ Khaidak village, August 2008.

${ }^{31}$ Khaidak village, August 2008.

${ }^{32}$ In Russian 'sochinit' means to 'create', 'write', 'compose', 'put together', 'invent'.

${ }^{33}$ Even the earliest, 19th-century records describing the Seto singing style were highly critical of the melodies, regarding their musical motivation as inadequately short and the performers' singing voices vulgar (see Schlegel 1831; also Kalkun 2011). Also, in the early 20th century, Karelians spoke of their earlier singing style in disparaging terms and considered singing these songs sinful (Huttu-Hiltunen 2009: 53ff.).

${ }^{34}$ Khaidak village, August 2008.

${ }^{35}$ Khaidak village, August 2008.

${ }^{36}$ Khaidak village choir; audio tape recorded by Igor Tõnurist, September 20, 1988.

${ }^{37}$ On the concept and meaning of the term 'cultural tradition' see, e.g., KirshenblattGimblett 1995; Kuutma 2009a.

${ }^{38}$ Assigning folk songs to types was adopted in the research methodology of the historicalgeographic school as a necessary step in identifying the age and origin of the songs, one that would facilitate comparison (see Bennett 2005 [1994]; Hafstein 2005; also Kalkun 2011: 91ff.).

${ }^{39}$ In their respective PhD theses, Liina Saarlo (2005: 31ff.) and Mari Sarv (2008: 121ff.) have studied the relationship of improvisation and tradition in the earlier Estonian folk song. Venla Sykäri (2011: 69ff.) has recently analysed the performance and poetics of Cretan improvisational songs; see also Jane C. Sugarman's (1997: 117ff.) work on Prespa Albanians' wedding songs. Even more recently, Žanna Pärtlas (2013) has investigated the different types of musical improvisation in Seto text-oriented singing culture. 
${ }^{40}$ See also the works of Finnish folklorist Leea Virtanen $(1981 ; 1987 ; 1994)$ who has, among other things, analysed the Setos' attitudes towards their songs.

${ }^{41}$ One of the most important Seto festivities in modern days. The festivity, which was initiated by Seto-born folklorist Paul Hagu in 1994, has become an annual celebration of increasing popularity. It entails elements of the traditional Seto kirmask (spontaneous singing, dancing, eating and drinking), but also various competitions, including one to find the best singer of the improvisational song - sõnoline.

${ }^{42} \mathrm{~A}$ persistent issue in Seto folklore is that of its belonging. The problem became particularly acute in 1930, when the collection and storing of Seto folklore in Estonian and Finnish archives was started (see Kalkun 2011; Kuutma 2009b).

${ }^{43}$ Krasnoyarsk Krai has a multiethnic population of indigenous groups, emigrants and deportees of various ethnicities. In 2006, a lavishly illustrated guide to ethnicities living in the Krasnoyarsk Krai was published, introducing 137 different ethnic groups, including Estonians and Setos (Rafikov 2006).

44 The use of specific Seto modes of melody has become rarer also among the Setos in Estonia. In the 1990s, only choirs of women of mostly advanced age sang songs in these modes (Pärtlas \& Oras 2012).

\section{REFERENCES}

Ambrazevičius, Rytis \& Pärtlas, Žanna 2011. Searching for the "Natural" Origins of the Symmetrical Scales: Traditional Multipart Setu Songs. Journal of Interdisciplinary Music Studies, Vol. 5, No. 1, pp. 1-17. Available at http://www.musicstudies.org/ jims201151/Ambrazevicius_JIMS_11050101.pdf, last accessed on May 23, 2014. Anderson, Benedict 1994 [1983]. Imagined Communities: Reflections on the Origin and Spread of Nationalism. London \& New York: Verso.

Bauman, Richard 1988 [1986]. Story, Performance, and Event: Contextual Studies of Oral Narrative. Cambridge: Cambridge University Press.

Bennett, Gillian 2005 [1994; doi:10.1080/0015587X.1994.9715871]. Geologists and Folklorists: Cultural Evolution and "The Science of Folklore". Folklore: Critical Concepts in Literary and Cultural Studies. Edited by Alan Dundes. Volume IV. Folkloristics: Theories and Methods. London \& New York: Routledge, pp. 370-393. Briggs, Charles L. 1988. Competence in Performance: The Creativity of Tradition in Mexicano Verbal Art. Philadelphia: University of Pennsylvania Press.

Buck, Willem 1909. Petseri eestlased. [Estonians in Pechory.] Tartu: Postimehe Kirjastus. Korb, Anu \& Peebo, Kadri (comps.) 1995. Siin Siberi maa peal kasvanud: Ülem-Suetuki ja Viru-Pulani lood ning laulud. Eesti asundused I. [Grown Up in Siberia: Stories and Songs from Verkhnii Suetuk and Verkhnaia Bulanka. Estonian Settlements, Vol. 1.] Tartu: Eesti Kirjandusmuuseum.

Hafstein, Valdimar Tr. 2005. Biological Metaphors in Folklore Theory: An Essay in the History of Ideas. Folklore: Critical Concepts in Literary and Cultural Studies. 
Edited by Alan Dundes. Volume IV. Folkloristics: Theories and Methods. London \& New York: Routledge, pp. 407-435.

Honko, Lauri \& Honko, Anneli \& Hagu, Paul 2003. The Maiden's Death Song \& The Great Wedding: Anne Vabarna's Oral Twin Epic written down by A. O. Väisänen. FF Communications, No. 281. Helsinki: Academia Scientiarum Fennica.

Hurt, Jakob 1904a. Über die pleskauer esten oder die sogenannten setukesen. Anzeiger der Finnisch-Ugrischen Forschungen. Band III, Heft 3. Helsingfors: Druckerei der Finnischen Literatur-Gesellschaft, pp. 185-205.

Hurt, Jakob 1989 [1904]. Kiri auustatud ajaloo-uurijale V. Reiman'ile. [A Letter to an Honoured Historian V. Reiman.] In: Ülo Tedre (comp.) Mida rahvamälestustest pidada. Artiklite kogumik. [What to Make of Folk Memory: A Collection of Articles.] Tallinn: Eesti Raamat, pp. 145-149.

Huttu-Hiltunen, Pekka 2009. Länsivienalainen runolaulu 1900-luvulla. Kuuden runolaulajan laulutyylin kulttuurisensitiivinen musiikkianalyysi. [Runosong in Western Vienna in the 20th Century.] Helsinki: Sibelius-Akatemia \& Kuhmo: Juminkeko.

Jääts, Indrek 1998. Setude etniline identiteet. [The Ethnic Identity of the Setos.] Studia Ethnologica Tartuensia 1. Tartu: Tartu Ülikooli etnoloogia õppetool.

Juhkason, Grethe \& Kalkun, Andreas \& Lindström, Liina \& Plado, Helen 2012. Petserimaa setodest ja nende keelest 2010.-2011. a. välitööde põhjal. [Setos of the Pechorsky District: On Their Current Situation and Their Language, Based on Fieldwork in 2010-2011.] Õdagumeresoomõ piiriq. Läänemeresoome piirid. Finnic borders. Võro Instituudi Toimõndusõq. Publications of Võro Institute 26. Võru: Võro Instituut, pp. 11-29.

Kalkun, Andreas 2004. Leiko: 40 aastat Värska leelokoori. [Leiko: 40th Anniversary of the Värska Choir.] Tallinn: Setumaa Kultuuriprogramm.

Kalkun, Andreas 2008. A Woman's Voice in an Epic: Tracing Gendered Motifs in Anne Vabarna's Peko. Journal of Ethnology and Folkloristics, Vol. 2, No. 2, pp. 25-45. Available at http://www.jef.ee/index.php/journal/article/view/28/pdf_27, last accessed on May 26, 2014.

Kalkun, Andreas 2011. Seto laul eesti folkloristika ajaloos. Lisandusi representatsiooniloole. [Seto Singing Culture in Studies of Estonian Folklore: A Supplement to the History of Representation.] Tartu: Tartu Ülikooli Kirjastus. Available at http://dspace. utlib.ee/dspace/bitstream/handle/10062/18222/kalkun_andreas.pdf?sequence=1, last accessed on May 26, 2014.

Kalkun, Andreas \& Korb, Anu (comps.) 2012. Siberi setode laulud. Songs of Siberian Seto. Pesni sibirskikh seto. Tartu: Eesti Kirjandusmuuseumi Teaduskirjastus.

Kalkun, Andreas \& Ojamaa, Triinu 2009. Orthodox Chanting and Traditional Singing: Conflicts and Compromises. In: Piotr Dahlig (ed.) Traditional Musical Cultures in Central-Eastern Europe: Ecclesiastical and Folk Transmission. Warsaw: University of Warsaw \& Polish Academy of Sciences, pp. 157-175. Available at http://laul.setomaa.ee/pdf/poola_artikkel.pdf, last accessed on May 26, 2014.

Kallio, Kati 2013. Laulamisen tapoja: Esitysareena, rekisteri ja paikallinen laji länsiinkeriläisessä kalevalamittaisessa runossa. [Ways of Singing: Performance Arena, 
Register and Local Genre in West-Ingrian Oral Poetry.] Helsinki: University of Helsinki. Available at https://helda.helsinki.fi/bitstream/handle/10138/42072/ vaitoskirja_Kallio_2013.pdf?sequence=1, last accessed on May 26, 2014.

Keem, Hella 1997. Võru keel. [Võro Language.] Tallinn: Eesti Teaduste Akadeemia Emakeele Selts.

Keem, Hella \& Käsi, Inge 2002. Võru murde tekstid: Eesti murded VI. [Texts in Võro Dialect: Estonian Dialects VI.] Tallinn: Eesti Keele Instituut.

Kirshenblatt-Gimblett, Barbara 1995. Theorizing Heritage. Ethnomusicology, Vol. 39, No. 3, pp. 367-380. http://dx.doi.org/10.2307/924627.

Korb, Anu 2005. Venemaal rahvuskaaslasi küsitlemas: folkloristliku välitöö metoodilisi aspekte. [Interviewing Estonians in Russia: Methodical Aspects of Folkloristic Fieldwork.] Studia Ethnologica et Folkloristica Tartuensia 9. Tartu: Tartu Ülikooli Kirjastus.

Kreutzwald, Friedrich Reinhold 1848. Mittheilung über Volkslieder bei den im Pleskauschen Gouvernement angesiedelten Esten, nebst einer Beilage mit Liederproben. In: Verhandlungen der gelehrten Estnischen Gesellschaft zu Dorpat. Zweiter band. Zweites Heft. Doprat: H. Laakmann, pp. 43-62.

Kuutma, Kristin 2005. Pärimuskultuurist kultuurisümboliks. Saami etnograafia ja seto eepose saamislugu. [From Traditional Culture to the Symbol of Culture: The Creation of Sami Ethnography and a Seto Epic.] EKLA töid kirjandusest ja kultuuriloost 3. Tartu: Eesti Kirjandusmuuseum.

Kuutma, Kristin 2006. Collaborative Representations: Interpreting the Creation of a Sámi Ethnography and a Seto Epic. FF Communications No. 289. Helsinki: Suomalainen tiedeakatemia.

Kuutma, Kristin 2009a. Cultural Heritage: An Introduction to Entanglements of Knowledge, Politics and Property. Journal of Ethnology and Folkloristics, Vol. 3, No. 2, pp. 5-12. Available at http://www.jef.ee/index.php/journal/article/view/9/ pdf_8, last accessed on May 26, 2014.

Kuutma, Kristin 2009b. Who Owns Our Songs? Authority of Heritage and Resources for Restitution. Ethnologia Europaea, Vol. 39, No. 2, pp. 26-40.

Laanemets, Liisi 2012. Seto identiteedi loomisest ja hoidmisest väljaspool Setomaad tegutseva leelokoori näitel. [Creating and Retaining Seto Identity: Case Study of a Seto Choir Existing Outside Setomaa.] Res musica 4. Eesti Muusikateaduse Seltsi ja Eesti Muusika-ja Teatriakadeemia muusikateaduse osakonna aastaraamat. [Yearbook of Estonian Musicological Society and Musicological Department of the Estonian Academy of Music and Theatre.] Tallinn: EMTS \& EMTA, pp. 75-96.

Lõuna, Kalle 2003. Petserimaa. Petserimaa integreerimine Eesti Vabariiki 1920-1940. [The Pechory Region and Its Integration into the Republic of Estonia 1920-1940.] Tallinn: Eesti Entsüklopeediakirjastus.

Muszkalska, Božena \& Polak, Tomasz 2009. Syncretism in the Musical Culture of the Polish Hollanders in Siberia. In: Piotr Dahlig (ed.) Traditional Musical Cultures in Central-Eastern Europe: Ecclesiastical and Folk Transmission. Warsaw: University of Warsaw \& Polish Academy of Sciences, pp. 213-226. 
Nigol, August 1918. Eesti asundused ja asupaigad Wenemaal. [Estonian Settlements and Places of Residence in Russia.] Tartu: Postimees. Available at http://ida.aule. ee/raamatud/nigol1918_orig.pdf, last accessed on May 27, 2014.

Olson, Laura J. \& Adonyeva, Svetlana 2012. The Worlds of Russian Village Women: Tradition, Transgression, Compromise. Madison: The University of Wisconsin Press.

Oras, Janika 2008. Viie 20. sajandi naise regilaulumaailm. Arhiivitekstid, kogemused ja mälestused. [The Regilaul World of Five 20th Century Women: Archival Texts, Experiences and Memories.] Eesti Rahvaluule Arhiivi Toimetused 27. Ed. by Mall Hiiemäe. Tartu: Eesti Kirjandusmuuseumi Teaduskirjastus.

Oras, Janika 2009. Lõik eesti folkloorikogumise loost: Nõukogude aja helisalvestused. [A Fragment from the History of Estonian Folklore Collection: Sound Recordings from the Soviet Period.] Akadeemia, No. 4, pp. 703-723.

Oras, Janika 2012. Recordings of Songs by Estonian Prisoners of War: Repertoire and Its Representations. In: Jaan Ross (ed.) Encapsulated Voices: Estonian Sound Recordings from the German Prisoner-of-War Camps in 1916-1918. Köln \& Weimar \& Wien: Böhlau Verlag, pp. 147-177.

Paas, Fr. E. 1928. Sega-abielud ja nende mõju rahvusesse piiriäärsetes maakondades Eestis. [Mixed Marriages and Their Effect on the Nation in Peripheral Counties in Estonia.] Eesti Kirjandus, No. 6, pp. 294-306. Available at http://www.digar. ee/arhiiv/nlib-digar:53307, last accessed on May 27, 2014.

Pajusalu, Karl 2000. Lõunaeesti murdeliigendusest. [About the Articulation of SouthEstonian Dialects.] In: K. Pajusalu \& S. Iva (eds.) Õdagumeresoome piirisü̈̈meq. Keskused läänemeresoome piiridel. [Centres at the Baltic-Finnic Borders.] Võro Instituudi toimõndusõq 10. Võro: Võro Instituut, pp. 76-86.

Pajusalu, Karl \& Hennoste, Tiit \& Päll, Peeter \& Niit, Ellen \& Viikberg, Jüri (comps.) 2009. Eesti murded ja kohanimed. [Estonian Dialects and Place Names.] Tallinn: Eesti Keele Sihtasutus.

Pärtlas, Žanna 1995. Mitmehäälsuse rollist erinevate rahvuslike folklooritraditsioonide vastastikusel mõjutamisel. [On the Role of Polyphony in the Reciprocal Influence of Various Folklore Traditions.] Eksitaja: Pro Folkloristica 3. Tartu: Eesti Kirjandusmuuseum, pp. 56-58. Available at http://www.folklore.ee/era/nt/PF3/, last accessed on May 27, 2014.

Pärtlas, Žanna 1997. Tähelepanekuid setu laulu laadiehitusest ja mitmehäälsusest. [Observations of Style and Polyphony of Seto Songs.] Teater. Muusika. Kino, No. 1, pp. 23-28. Available at http://www.digar.ee/arhiiv/et/perioodika/104168, last accessed on May 27, 2014.

Pärtlas, Žanna 2010. Setu Multipart Singing: Comparison of Written Sources and Sound Recordings. In: Susanne Ziegler \& Urban Bareis (eds.) Historical Sources and Source Criticism. Stockholm: Svenskt Visarkiv, pp. 227-237.

Pärtlas, Žanna 2013. On Musical Creativity in "Text-Oriented" Song Traditions: The Processes of Melodic Variation in Seto Multipart Songs. In: Ardian Ahmedaja (ed.) Local and Global Understandings of Creativities: Multipart Music Making and the Construction of Ideas, Contexts and Contents. Cambridge: Cambridge Scholars Publishing, pp. 60-76. 
Pärtlas, Žanna \& Oras Janika 2012. Seto traditsioonilise laulumaneeri jäljendamise eksperimendist. [Results from an Experiment in Emulating the Traditional Seto Singing Style.] Res musica 4. Eesti Muusikateaduse Seltsi ja Eesti Muusika- ja Teatriakadeemia muusikateaduse osakonna aastaraamat. [Yearbook of Estonian Musicological Society and Musicological Department of the Estonian Academy of Music and Theatre.]. Tallinn: EMTS \& EMTA, pp. 22-43.

Piho, Mare 1994. Setukaiskylät Siperiassa. [Seto Villages in Siberia.] Helsinki: Tuglasseura.

Rafikov, R. (ed.) 2006. Etnoatlas Krasnoiarskogo kraia. [Ethnographic Atlas of Krasnoyarsk Krai.] Krasnoiarsk: Platina.

Raun, Toivo U. 1991. The Petseri Region of the Republic of Estonia. Jahrbücher für Geschichte Osteuropas, Vol. 39, pp. 514-532. Available at http://daten.digitalesammlungen.de/ db/bsb00003839/images/index.html?fip=193.174.98.30\&seite= 538\&pdfseitex=, last accessed on May 27, 2014.

Raun, Toivo U. 2007. The All-Estonian Congress in Tartu, November 1905: A Reassessment. Journal of Baltic Studies, Vol. 38, No. 4, pp. 383-400. http:// dx.doi.org/10.1080/01629770701682624.

Rüütel, Ingrid 1983. Eesti uuemad laulumängud 2. [Newer Estonian Singing Games II.] Tallinn: Eesti Raamat.

Rüütel, Ingrid 1998. Estonian Folk Music Layers in the Context of Ethnic Relations. Folklore: Electronic Journal of Folklore, Vol. 6, pp. 32-69. doi:10.7592/FEJF1998.06. ruutel.

Rüütel, Ingrid 2012. Eesti uuema rahvalaulu kujunemine. [The Formation of the Newer Estonian Folk Song.] Tartu: Eesti Kirjandusmuuseumi Teaduskirjastus.

Saarlo, Liina 2005. Eesti regilaulude stereotüüpiast. Teooria, meetod ja tähendus. [The Stereotypy of Estonian Runo Songs: Theory, Method and Meaning.] Dissertationes Folkloristicae Universitatis Tartuensis 5. Tartu: Tartu Ülikooli Kirjastus.

Särg, Taive 2012. Paralleelsed või lõikuvad sirged? Torrõ ja killõ helikõrgustest kahes seto laulus akustiliste mõõtmiste põhjal. [Changes in Melody Scale in the Course of Gradual Rise of Pitch in Seto Folk Song: The Results of Acoustic Measurements of Upper Voice killõ and Lower Voice torrõ.] Res Musica 4, pp. 44-62.

Sarv, Mari 2008. Loomiseks loodud: regivärsimõõt traditsiooniprotsessis. [Made for Making: Runo-Song Metre in the Process of Tradition.] Eesti Rahvaluule Arhiivi Toimetused 26. Tartu: Eesti Kirjandusmuuseumi Teaduskirjastus.

Sarv, Vaike 1997. Setu improvisatsioonid esimesel Kuninga kuulutamisel. [Seto Improvisations at the Announcing of the First King.] Lee 4. Ümin. Tartu: Eesti Rahva Muuseumi Sõprade Selts, pp. 79-95.

Sarv, Vaike 2000. Setu itkukultuur. [Seto Lamenting Culture.] Ars Musicae Popularis, Vol. 14. Tartu: Eesti Kirjandusmuuseum, etnomusikoloogia osakond \& Tampere: Tampereen yliopiston kansanperinteen laitos. 
Schlegel, Christian Hieronymus Justus 1831. Reisen in mehrere russische Gouvernements in den Jahren 1801, 1807, 1815, 1830. Sechstes Bändchen. Reise von St. Petersburg nach dem Pleskowschen Gouvernement im Monat Julius 1815. Meiningen: Friedemann Keyßner. Available at http://dspace.utlib.ee/dspace/ handle/10062/36306, last accessed on May 27, 2014.

Seto leelo 2009 = Seto Leelo, Seto polyphonic singing tradition. The Representative List of the Intangible Cultural Heritage of Humanity. Available at http://www.unesco. org/culture/ich/index.php?RL=00173, last accessed on May 27, 2014.

Shchurov 2007 = Shchurov, Viacheslav Mikhailovich. Zhanry russkogo muzykal'nogo fol'klora I. Istoriia, bytovanie, muzykal'no-poeticheskie osobennosti. [Genres of Russian Musical Folklore I.] Moskva: Muzyka.

Sugarman, Jane C. 1997. Engendering Song: Singing and Subjectivity at Prespa Albanian Weddings. Chicago Studies in Ethnomusicology. Chicago and London: University of Chicago Press.

Sykäri, Venla 2011. Words as Events: Cretan Mantinádes in Performance and Composition. Helsinki: Finnish Literature Society.

Tarkka, Lotte 2005. Rajarahvaan laulu. Tutkimus Vuokkiniemen kalevalamittaisesta runokulttuurista 1821-1921. [Songs of the Border People: Kalevala-Metre Poetry in Vuokkiniemi Parish 1821-1921.] Helsinki: Suomalaisen Kirjallisuuden Seura.

Timonen, Senni 2004. Minä, tila, tunne. Näkökulmia kalevalamittaiseen kansanlyriikkaan. [Self, Space, Emotion: Aspects of Kalevala-Metre Folk Lyric.] Suomalaisen Kirjallisuuden Seuran Toimituksia 963. Helsinki: Suomalaisen Kirjallisuuden Seura.

Ustav, Karl 1908. Pihkwa eestlased. [Estonians of Pskov.] Kirjutanud K. Usstaw. Tartu: Postimehe Kirjastus.

Virtanen, Leea 1981. Setukaisnaisten lauluperinne. [The Song Tradition of Seto Women.] Suomen Antropologi, No. 1, pp. 29-40.

Virtanen, Leea 1987. Setukaiset kertovat lauluistaan. [The Setos Speak of Their Songs.] In: Leea Virtanen (ed.) Viron veräjät: Näkökulmia folkloreen. Tietolipas 105. [Estonian Gates: Views on Folklore.] Helsinki: Suomalaisen Kirjallisuuden Seura, pp. 161-194.

Virtanen, Leea 1994. Singers on their Songs: The Act of Singing as Perceived by Singers in the Setu Region of Estonia Today. In: Michael Branch \& Celia Hawkesworth (eds.) The Uses of Tradition: A Comparative Enquiry into the Nature, Uses and Functions of Oral Poetry in the Balkans, the Baltic, and Africa. London: School of Slavonic and East European Studies, University of London, pp. 231-249. 


\section{ONLINE SOURCES}

a-pesni $=$ Dvorovye $i$ blatnye. [Songs from Street and Prison.] http://a-pesni.org/dvor/ Dvor.php, last accessed on May 28, 2014.

Antologiia $=$ Antologiia odnoi pesni . [Anthology of One Song.] Ia vstretil rozu ... [I Met a Rose...] http://shanson-e.tk/forum/archive/index.php/t-68321.html, last accessed on May 28, 2014.

Dvorovye romansy $=$ Dvorovye romansy nachala 70- $k$ h. [Street Romances from the Beginning of the 1970s.] http://music.lib.ru/b/boris_d/alb1.shtml, last accessed on May 28, 2014. 